\title{
Phlorizin treatment of diabetic rats partially reverses the abnormal expression of genes involved in hepatic glucose metabolism
}

\author{
S.M. Brichard ${ }^{1}$, J.C. Henquin ${ }^{2}$ and J. Girard ${ }^{1}$ \\ Centre de Recherche sur l'Endocrinologie Moléculaire et le Développement, CNRS, Meudon, France \\ ${ }^{2}$ University of Louvain, Endocrinology and Metabolism, Faculty of Medicine, Brussels, Belgium
}

\begin{abstract}
Summary. Liver insulin resistance and glucagon-stimulated hepatic glucose production are characteristics of the diabetic state. To determine the potential role of glucose toxicity in these abnormalities, we examined whether phlorizin treatment of streptozotocin-diabetic rats resulted in altered expression of genes involved in key steps of hepatic glucose metabolism. By inhibiting renal tubular glucose reabsorption, phlorizin infusion to diabetic rats induced normoglycaemia, did not significantly alter low circulating insulinaemia, but caused a marked decrease in hyperglucagonaemia. Glucokinase and L-type pyruvate kinase mRNA levels were reduced respectively by $90 \%$ and $70 \%$ in fed diabetic rats, in close correlation with changes in enzyme activities. Eighteen days of phlorizin infusion partially restored glucokinase mRNA and activity ( $40 \%$ of control levels), but had no effect on L-type pyruvate kinase mRNA and activity. In contrast to the glycolytic enzymes, mRNA and activity of the gluconeogenic enzyme, phospoenolpyruvate carboxykinase were increased (10- and 2.2-fold, respectively) in fed diabetic rats. Phlorizin
\end{abstract}

administration decreased phospoenolpyruvate carboxykinase mRNA to values not different from those in control rats, while phospoenolpyruvate carboxykinase activity remained $50 \%$ higher than that in control rats. The $50 \%$ rise in liver glucose transporter (GLUT 2) mRNA and protein, produced by diabetes, was also corrected by phlorizin treatment. In conclusion, we propose that phlorizin treatment of diabetic rats may induce a partial shift of the predominating gluconeogenesis, associated with hepatic glucose overproduction, into glycolysis, by correction of impaired pre-translational regulatory mechanisms. This could be essentially mediated through improved pancreatic alpha-cell function and subsequent lowering of hyperglucagonaemia. These observations suggest that glucagon-stimulated hepatic glucose production may result, in part, from glucose toxicity.

Key words: Diabetes mellitus, phlorizin, glucagon, hepatic glucose metabolism, gene expression.
Defects in insulin secretion and insulin action are major features of the pathogenesis of both Type 1 (insulin-dependent) and Type 2 (non-insulin-dependent) diabetes mellitus in man, and similar disturbances have been shown in animal models of diabetes. It is well-established that an initial defect in insulin secretion can lead to the development of insulin resistance [1]. The latter appears first in the liver, then in peripheral tissues of rats made diabetic by streptozotocin injection [2]. During the last decade, it has been recognized that chronic hyperglycaemia itself may play a pathogenic role in diabetes by maintaining a self-perpetuating cycle of metabolic deterioration and the concept of glucose toxicity has emerged $[3,4]$. The first evidence presented was that hyperglycaemia per se may attenuate the secretory response of pancreatic islet cells to glucose in some animal models of diabetes [5-7]. It has been further demonstrated that chronic hyperglycaemia may impair the effects of insulin on glucose uptake by pe- ripheral tissues $[3,8-11]$ and on glucose production by the liver [10].

It has been suggested that, in insulin-deficient rats, hyperglycaemia-induced peripheral insulin resistance involved a down-regulation of the glucose transporter isoform GLUT 4 (decreased number in the plasma membrane) or an impairment of its intrinsic activity in muscle and adipose tissue or both $[12,13]$. The mechanisms underlying hyperglycaemia-induced liver insulin resistance have not yet been determined.

Phlorizin treatment of diabetic rats, by inhibiting renal tubular glucose reabsorption, leads to near normal fed plasma glucose levels without significantly altering low fed plasma insulin levels. Such treatment has been shown to restore insulin action not only in peripheral tissues [9-11], but also in liver [10] of insulin-deficient animals. In the present study, we administered phlorizin as a continuous subcutaneous infusion to streptozotocin-diabetic rats 
for 18 days. Then, we examined whether mere correction of hyperglycaemia by glucuresis reversed the abnormal expression of genes involved in hepatic glucose metabolism. This was achieved by measuring mRNA levels of glycolytic [glucokinase (GK) and L-type pyruvate kinase (L-PK)] and gluconeogenic [phosphoenolpyruvate carboxykinase (PEPCK)] enzymes, and of the glucose transporter isoform (GLUT 2) in liver of phlorizin-treated rats.

\section{Materials and methods}

\section{Animals and experimental design}

Male Wistar rats ( 8 weeks old; $224 \pm 1 \mathrm{~g}$ ) were purchased from IFFA Credo (L'Abresle, France). All rats received ad libitum a standard laboratory chow (Extralabo M-25; Ets. Pietrement, Provins, France; $\%$ of total energy (calories/calories): $60 \%$ carbohydrate, $11 \%$ fat, $29 \%$ protein) and were housed in individual cages at a constant temperature $\left(22^{\circ} \mathrm{C}\right.$ ). A 12-h-light-dark cycle was set up (lights on $03.00-$ 15.00 hours) with liver samples taken during the absorptive state of the animals (between 08.00-10.00 hours) at the end of the study.

The animals were divided into three experimental groups: nondiabetic control rats ( $\mathrm{C} ; n=5$ ); untreated diabetic rats (D;n=5); diabetic rats treated with phlorizin (PHL; $n=5$ ). Non-ketotic diabetes was induced by an i.v. injection of streptozotocin $(45 \mathrm{mg} / \mathrm{kg}$ body weight) into a tail vein. Streptozotocin (Sigma, St Louis, Mo., USA) was dissolved in cold $0.1 \mathrm{~mol} / /$ citrate buffer ( $\mathrm{pH} 4.5$ ) immediately before use. Control animals received only the buffer. Five days after injection of streptozotocin, the diabetic rats were assigned to untreated or treated groups. The two groups of diabetic rats were matched for pre-treatment body weight (D: $249 \pm 3 \mathrm{~g}$, PHL: $240 \pm 4 \mathrm{~g}, p>0.05$ ) and for pre-treatment fed plasma glucose levels (D; $25.6 \pm 1.4 \mathrm{mmol} / \mathrm{l}, \mathrm{PHL}: 26.2 \pm 1.7 \mathrm{mmol} / \mathrm{l}, p>0.05$ ). The treated group received phlorizin (Sigma, $0.4 \mathrm{~g} / \mathrm{kg}$ body weight per day, dissolved in propylene glycol) as a subcutaneous injection in two equally divided doses during the first 3 days, and thereafter as a continuous subcutaneous infusion via an implantable mini-pump. The osmotic mini-pump allowed for continuous inhibiton of renal tubular resorption of glucose and maintenance of a tighter glycaemic control. This pump (Alzet model 2 ML1; Alza Corp., Palo Alto, Calif., USA) was implanted under light ether anaesthesia, removed after 1 week of use and replaced by a second pump to obtain a 18-day phlorizin exposure period. Animals from the three groups were handled frequently to minimize non-specific reactions that could occur during blood sampling.

On several occasions, tail vein blood was collected from conscious fed animals for determination of plasma glucose and insulin levels. Plasma glucagon concentrations were also measured on days 5 and 17 of the study. Samples were collected into ice-cold heparinized tubes which were rapidly centrifuged. Plasma glucagon was protected from degradation by a trypsin inhibitor, Iniprol (Laboratoires Choay, Paris, France).

After 18 days of treatment, animals were killed between $08.00-$ 10.00 hours (i. e. in the absorptive state). The liver was immediately removed, frozen in liquid nitrogen and stored at $-80^{\circ} \mathrm{C}$ for subsequent mRNA extraction, crude membrane preparation and enzyme activity measurement.

\section{RNA extraction and Northern blot analysis}

Total RNA was isolated by a single extraction with an acid guanidinium thiocyanate-phenol-chloroform mixture [14]. The concentration of RNA was determined by absorbance at $260 \mathrm{~nm}$. All samples had a 260/280 absorbance ratio of about 2 . For Northern blot analysis, RNA $(30 \mu \mathrm{g})$ was denaturated in a solution containing $2.2 \mathrm{mmol} / \mathrm{l}$ formaldehyde and $50 \%$ formamide (volume/volume) by heating at $95^{\circ} \mathrm{C}$ for $2 \mathrm{~min}$. RNA was then size-fractionated by $1 \%$ agarose gel electrophoresis, transferred to a Hybond-N membrane (Amersham Int., Amersham, Bucks, UK) and cross-linked by ultraviolet irradiation. The integrity and relative amounts of RNA were assessed by methylene blue staining of the blot.

The GK, L-PK, PEPCK and GLUT 2 cDNA probes were kindly supplied by Drs. P. Iynedjian [15], A. Kahn [16], R. W Hanson [17] and $B$. Thorens [18], respectively. Probes were labelled with ${ }^{32} \mathrm{P}$ using the Megaprime labelling system kit (Amersham). Hybridizations with L-PK, PEPCK or GLUT 2 probes were carried out in medium containing denatured salmon sperm DNA $(0.3 \mathrm{mg} / \mathrm{ml}), 42 \%$ deionized formamide, $7.5 \%$ dextran sulphate, $8 \times$ Denhardt's solvtion (Denhardt $1 \times: 0.2 \mathrm{~g} / \mathrm{l}$ polyvinylpyrrolidone, $0.2 \mathrm{~g} / 1$ bovine serum albumin, $0.2 \mathrm{~g} / \mathrm{l}$ ficoll 400$), 40 \mathrm{mmol} / \mathrm{l}-\mathrm{Tris} / \mathrm{HCl}(\mathrm{pH} 7.5)$, $0.1 \%$ sodium pyrophosphate and $1 \%$ sodium dodecyl sulphate (SDS) at $42^{\circ} \mathrm{C}$ overnight. Hybridization with GK probe was performed in $3 \times$ sodium saline phosphate ethylenediamine tetraacetic acid (SSPE) buffer, $1 \%$ SDS, $1 \%$ glycine, $0.2 \%$ ficoll, $0.2 \%$ polyvinylpyrrolidone, $10 \%$ polyethylene glycol and denaturated salmon sperm DNA $(0.2 \mathrm{mg} / \mathrm{ml})$ at $65^{\circ} \mathrm{C}$ overnight. The membrane was washed two times for $30 \mathrm{~min}$ in $2 \times$ sodium saline citrate (SSC) buffer $10.1 \%$ SDS at $42^{\circ} \mathrm{C}$ and once for $15-30 \mathrm{~min}$ in $0.1-0.5 \times \mathrm{SSC} 10.1 \%$ SDS at $55^{\circ} \mathrm{C}$ (PEPCK, GLUT 2) or $65^{\circ} \mathrm{C}$ (L-PK). The membrane hybridized with GK was washed two times for $20 \mathrm{~min}$ in $2 \times \mathrm{SSPE} / 1 \%$ SDS and once for $15 \mathrm{~min}$ in $0.5 \times \mathrm{SSPE} / 1 \% \mathrm{SDS}$ at $65^{\circ} \mathrm{C}$. The filters were then exposed to Fuji X-Ray films for $7-48 \mathrm{~h}$ at $-80^{\circ} \mathrm{C}$ with intensifying screens.

Intensity of the mRNA bands on the blots was quantified by scanning densitometry (Hoefer, San Francisco, Calif., USA).

\section{Membrane preparation and Western blot analysis}

Total liver membranes were prepared according to Thorens et al. [18]. Briefly, tissue $( \pm 200 \mathrm{mg})$ was homogenized with 10 strokes of a motor-driven Teflon pestle in 20 volumes of $0.25 \mathrm{~mol} / \mathrm{l} \mathrm{suc-}$ rose $/ 25 \mathrm{mmol} / \mathrm{l}$ Hepes buffer ( $\mathrm{pH} 7.4$ ) containing $3 \mathrm{mmol} / \mathrm{l}$ dithiothreitol, $0.26 \mathrm{U} / \mathrm{ml}$ aprotinin, $0.1 \mathrm{mmol} / /$ phenylmethylsulphonyl fluoride. This homogenate was centrifuged for $10 \mathrm{~min}$ at $8000 \mathrm{~g}$ and the supernatant was centrifuged again for $20 \mathrm{~min}$ at the same speed. The cytosol was then centrifuged for $40 \mathrm{~min}$ at $150000 \mathrm{~g}$ and the membrane pellet was resuspended in phosphate-buffered saline $(8 \mathrm{~g} / 1$ $\mathrm{NaCl}, 0.2 \mathrm{~g} / \mathrm{KCl}, 1.44 \mathrm{~g} / 1 \mathrm{NaH}_{2} \mathrm{PO}_{4}, 0.24 \mathrm{~g} / 1 \mathrm{KH}_{2} \mathrm{PO}_{4}$; $\mathrm{pH}$ 7.4). Protein content was measured by the method of Bradford [19] (BioRad, Munich, FRG), using bovine serum albumin as standard.

Equal amounts of membrane proteins $(100 \mu \mathrm{g})$ were solubilized in Laemmli buffer [20], submitted to a 12\% SDS-PAGE and electrophoretically transferred to nitrocellulose membranes (Schleicher \& Schuell, Dassel, FRG). Rainbow protein markers were used as molecular weight standards and also to assess the efficiency of the transfer. Filters were then processed as previously described [18]. After blocking, the membranes were incubated with a $10^{-2}$ dilution of anti-peptide antibody directed against GLUT 2 (a gift from Dr B. Thorens). The detection was performed with $0.1 \mu \mathrm{Ci} / \mathrm{ml}^{125} \mathrm{I}$-protein $\mathrm{A}$, followed by autoradiography and subsequent quantification by scanning densitometry.

\section{Measurement of enzyme activities}

All enzyme activities were carried out at $37^{\circ} \mathrm{C}$. GK (EC 2.7.1.1) activity was determined using a spectrophotometric assay [21] by subtracting the hexokinase activity measured at $0.5 \mathrm{mmol} / \mathrm{lglucose}$ from the activity measured at $100 \mathrm{mmol} / \mathrm{lglucose}$. Results were expressed as $\mu \mathrm{mol}$ NADH produced $\cdot \mathrm{min}^{-1} \cdot \mathrm{g} \mathrm{liver}^{-1}$. L-PK (EC 2.7.1.40) was measured according to Blair et al. [22] at a subsaturating concentration of phosphoenolpyruvate (PEP) (1.3 mmol/l) (active form of the enzyme) and at saturating concentration of PEP ( $6.6 \mathrm{mmol} / \mathrm{l})$ (maximal activity of the enzyme). Results were expressed as $\mu$ mol NADH 
Table 1. Body weight gain and plasma glucose, insulin and glucagon levels in fed rats of the three experimental groups

\begin{tabular}{|c|c|c|c|c|}
\hline & \multicolumn{3}{|l|}{ During treatment } & \multirow{2}{*}{$\begin{array}{l}\text { End of treatment } \\
\text { Plasma glucagon } \\
\text { (pg/ml) }\end{array}$} \\
\hline & $\begin{array}{l}\text { Body weight gain } \\
\text { (g/day) }\end{array}$ & $\begin{array}{l}\text { Plasma glucose } \\
(\mathrm{mmol} / \mathrm{l})\end{array}$ & $\begin{array}{l}\text { Plasma insulin } \\
\text { (ng/ml) }\end{array}$ & \\
\hline Control & $4.2 \pm 0.3$ & $7.2 \pm 0.2$ & $3.67 \pm 0.29$ & $191 \pm 8$ \\
\hline Diabetic + phlorizin & $2.7 \pm 0.6^{\mathrm{a}}$ & $9.0 \pm 0.6^{c}$ & $1.78 \pm 0.14^{\mathrm{b}}$ & $191 \pm 17^{\circ}$ \\
\hline
\end{tabular}

${ }^{\mathrm{a}} p<0.05,{ }^{\mathrm{b}} p<0.01$ vs control rats; ${ }^{\mathrm{c}} p<0.01$ vs diabetic rats Values are means $\pm S E M$ for five rats in each group. Diabetes was induced by an i.v. injection of streptozotocin 5 days before the treatment. A group of diabetic rats was untreated; another group received subcutaneous infusion of phlorizin from day 0 to day 18 . Control rats were not injected with streptozotocin (only with citrate buffer) and did not receive phlorizin. Three samples were taken for plasma glucose and insulin measurements during the treatment period (days 5, 12,17); the values obtained were averaged for each rat. Values of plasma glucagon are those determined at the end of the study (day 17)

Table 2. Effects of phlorizin treatment on L-type pyruvate kinase (L-PK), glucokinase (GK), phosphoenolpyruvate carboxykinase (PEPCK) activities and on GLUT 2 protein in liver of diabetic rats

\begin{tabular}{llcccc}
\hline & L-PK & GK & PEPCK & GLUT 2 Protein \\
\cline { 2 - 3 } & PEP 1.3 mmol/l & PEP 6.6 mmol/1 & & $\%$ of controls \\
Control & $\mu$ mol of substrate transformed per min per g of liver & & $100 \pm 21$ \\
Diabetic & $40.5 \pm 6.3$ & $65.6 \pm 5.7$ & $3.64 \pm 0.30$ & $1.11 \pm 0.09$ & $165 \pm 37$ \\
Diabetic + phlorizin & $8.9 \pm 1.5^{\mathrm{b}}$ & $17.8 \pm 2.4^{\mathrm{b}}$ & $0.26 \pm 0.02^{\mathrm{b}}$ & $2.45 \pm 0.19^{\mathrm{b}}$ & $1.6 \pm \pm 21$ \\
\hline
\end{tabular}

${ }^{a} p<0.05,{ }^{b} p<0.01$ vs control rats; ${ }^{c} p<0.01$ vs diabetic rats Values are means \pm SEM for five rats in each group. The animals were killed in the fed state after 18 days of treatment. GLUT 2 pro- tein was measured by western blot analysis, quantified by scanning densitometry and expressed as a percentage of control rats. PEP, Phosphoenolpyruvate oxidized $\cdot \mathrm{min}^{-1} \cdot \mathrm{g} \mathrm{liver}^{-1}$. PEPCK (EC 4.1.1.32) activity was determined in liver cytosolic fractions using the $\mathrm{NaH}\left[{ }^{14} \mathrm{C}\right] \mathrm{O}_{3}$ fixation assay of Chang and Lane [23]. Results were expressed as $\mu \mathrm{mol}$ $\mathrm{NaH}\left[{ }^{14} \mathrm{C}\right] \mathrm{O}_{3}$ fixed $\cdot \mathrm{min}^{-1}, \mathrm{gliver}{ }^{-1}$.

\section{Analytical procedures}

Plasma glucose was measured by a glucose oxidase method (Peridochrom; Boehringer-Mannheim, Mannheim, FRG). Plasma insulin was determined by a double-antibody radioimmunoassay, using rat insulin as standard (Novo Research Institute, Bagsvaerd, Denmark). Plasma glucagon was measured by a radioimmunoassay using a charcoal separation step and the antiserum 04A, which is considered to be specific for pancreatic glucagon (Dr. R.H. Unger, Dallas, Tx., USA).

\section{Statistical analysis}

Results are given as the mean \pm SEM for the indicated number of rats. Comparisons between control, diabetic, and phlorizin-treateddiabetic rats were carried out by analysis of variance followed by the Newman-Keuls test for multiple comparisons [24]. Student's $t$-test for paired data was used to evaluate the time course of phlorizin effect on plasma insulin levels. Differences were considered statistically significant at $p<0.05$.

\section{Results}

Diabetic rats gained weight at a much lower rate than controls. This growth retardation was not improved by phlorizin treatment (Table 1).
Average plasma glucose levels in fed diabetic rats were above $25 \mathrm{mmol} / 1$ and their plasma insulin levels were decreased by more than $50 \%$. Phlorizin administration to diabetic rats resulted in a normalization of plasma glucose concentrations (Table 1). The correction of hyperglycaemia was observed as early as after 5 days of treatment and persisted until the end of the experiment. This effect was not due to a rise in plasma insulin levels, which did not change throughout the study (day 5 vs day $17, p>0.05$ by paired $t$-test) and remained low in fed phlorizin-treated diabetic rats (Table 1). Plasma glucagon levels were increased by $75 \%$ in diabetic animals. This rise was totally prevented by 17 days of phlorizin administration (Table 1). The glucagon-lowering effect induced by phlorizin was not observed after 5 days of treatment (data not shown).

Protracted hyperglycaemia in diabetic rats was associated with overt polydipsia: their daily fluid consumption was four-fold greater than in control rats (D: $188 \pm 12 \mathrm{ml} /$ day vs $\mathrm{C}: 40 \pm 4 \mathrm{ml} /$ day, $p<0.01$ ). Although reduced, fluid intake in phlorizin-treated diabetic rats $(107 \pm 2 \mathrm{ml} /$ day) remained two-fold higher than in controls $(p<0.01$ ), which probably reflects the increased urinary losses of glucose produced by the treatment.

To determine whether relief of hyperglycaemia by phlorizin glucuresis was associated with altered expression of genes involved in key steps of hepatic glucose metabolism, we measured mRNA levels of glycolytic and gluconeogenic enzymes, and of the GLUT 2 transporter isoform. Yields of total RNA in liver did not differ between the three groups (C: $4.2 \pm 0.4 \mathrm{mg} / \mathrm{g}$; D: $5.1 \pm 0.6 \mathrm{mg} / \mathrm{g}$, PHL: $4.7 \pm 0.3 \mathrm{mg} / \mathrm{g})$. The abundance of mRNAs encoding the glycolytic enzymes, L-PK and GK, 


\section{L-PK m RNA}
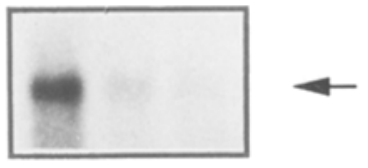

$3.2 \mathrm{~kb}$

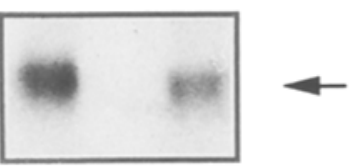

$2.4 \mathrm{~kb}$

GK m RNA

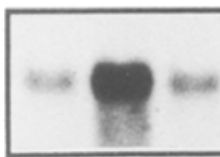

PEPCK MRNA

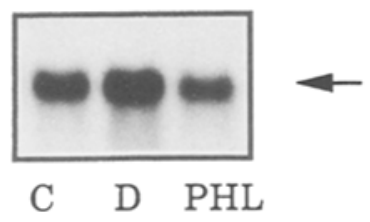

$2.8 \mathrm{~kb}$

GLUT 2 mRNA

was assessed by Northern blot analysis. L-PK and GK mRNA transcripts (3.2 and 2.4 kilobases $(\mathrm{kb}$ ), respectively) were barely detectable in diabetic liver (Fig. 1). Quantification of autoradiographic signals showed that L-PK and GK mRNAs were decreased, respectively by $70 \%$ and $90 \%$, in diabetic rats compared with control rats (Fig. 2). The activities of L-PK (at submaximal and maximal PEP concentrations) and GK were lowered accordingly (Table 2). Phlorizin treatment given to streptozotocin-diabetic rats for 18 days did not modify L-PK mRNA and activity. However, this treatment restored GK mRNA and activity to $41 \%$ and $43 \%$ of control levels, respectively. Compared to untreated diabetic rats, GK mRNA and activity were increased 20- and five-fold, respectively, in liver of phlorizin-treated rats (Figs. 1 and 2, Table 2).

Diabetes induced a 10-fold rise in mRNA levels of the gluconeogenic enzyme, PEPCK (Figs. 1 and 2), and a 2.2fold rise in the enzyme activity, as compared to control rats (Table 2). Phlorizin administration decreased PEPCK mRNA to values not significantly different from those in control rats, while PEPCK activity remained only slightly higher than that in controls (50\%) (Figs. 1 and 2, Table 2).

Glucose transport in liver is mostly mediated by GLUT 2, the glucose transporter isoform which is involved in either net glucose uptake or release depending on the prevailing metabolic conditions. Examination of GLUT 2 mRNA transcript ( $2.8 \mathrm{~kb})$ abundance on Northern blots indicated that levels of these liver transcripts were increased by $50 \%$ in diabetic liver (Figs. 1 and 2). The amount of GLUT 2 protein was measured by Western blot analysis in crude liver membranes. GLUT 2 protein levels were slightly increased by diabetes (Table 2 ). Altered abundance of GLUT 2 mRNA and protein was corrected upon treatment of diabetic rats with phlorizin.

\section{Discussion}

We confirmed that chronic administration of phlorizin to streptozotocin-diabetic rats normalized their fed plasma glucose levels without significantly altering their fed plasma insulin levels. We further showed that this treatment also corrected their fed hyperglucagonaemia and partially corrected the abnormal expression of genes involved in hepatic glucose metabolism.

In a previous study, no change in basal plasma glucagon levels was observed in diabetic rats after chronic phlorizin treatment [25]. However, the partially pancreatectomized rat model was used which did not exhibit absolute hyperglucagonaemia [25] due to a $70 \%$ decrease in its pancreatic glucagon content [5]. In the present work, hyperglucagonaemia is clearly present in streptozotocin-diabetic rats. Several mechanisms could theorically contribute to the glucagon-lowering effect induced by phlorizin in these animals. First, a direct action of phlorizin on alpha cells. This is unlikely, since direct perfusion of the drug into the isolated pancreas did not alter glucagon secretion [6]. Second, the circulatory arrangement within islets exposes alpha cells to the highest circulating insulin concentrations in the body and facilitates a role for insulin as an in-

Fig. 2A-D. Effects of phlorizin treatment on $\mathbf{A}$, L-type pyruvate kinase, B, phosphoenolpyruvate carboxykinase, C, glucokinase, and $\mathbf{D}$, GLUT 2 transporter mRNA levels in liver of diabetic rats. Values are means $\pm S E M$ for five control (C), untreated diabetic (D) and phlorizin-treated diabetic (PHL) rats. mRNA levels were quantified by scanning densitometry of autoradiographic signals obtained from a Northern blot hybridized successively with the different radiolabelled cDNA probes. Results were expressed as percentages of values in control rats. Statistical significance of differences (analysis of variance followed by Newman-Keuls test): " $p<0.05, " p<0.01$ vs control rats; $\uparrow p<0.05$, †† $p<0.01$ vs untreated diabetic rats 
hibiting factor for glucagon release [26]. Fed plasma insulin concentrations, measured throughout this study, did not significantly increase in diabetic rats treated with phlorizin. This is in agreement with previous reports which further showed that phlorizin did not alter insulin secretion in response to a meal or an $i . v$. glucose bolus in similarly mildly insulin-deficient rats $[7,9,10,25]$. However, minute restoration of glucose induced-insulin release cannot be excluded. Some restoration of beta-cell function, barely detectable by the tests mentioned above, has been observed during hyperglycaemic clamp studies performed in partially pancreatectomized rats chronically treated with phlorizin [7]. It should be emphasized, however, that in these studies, the plasma insulin response remained small, when considered in absolute terms, and did not exceed $15 \%$ of that in control rats [7]. Third, it has been suggested that alpha cells have a glucose-sensing system that functions independently of insulin and beta cells and that this system may be attenuated by chronic hyperglycaemia. A rise in glucose concentration does not suppress glucagon release in the insulin-deficient diabetic state [27], which it normally does. Strong evidence that diabetic alpha-cell "blindness" to glucose can be reversed, despite continuing insulin deficiency, by mere correction of hyperglycaemia with phlorizin, has been obtained in totally insulin-deprived dogs [6]. The normal decrease in plasma glucagon levels in response to a physiological rise in glycaemia was restored in phlorizin-treated (normoglycaemic) diabetic dogs [6]. Such a mechanism is likely to play a determining role in the normalization of glucagonaemia, as shown in the present study in long-term phlorizin-treated diabetic rats.

It has been reported that chronic administration of glucagon to normal rats modified a number of hepatic enzyme activities (including L-PK and PEPCK), mainly by affecting enzyme levels [28]. Since chronic hyperglucagonaemia opposes the suppressive effect of insulin on hepatic glucose production [29] and since liver insulin resistance in diabetic rats has been shown to be corrected by phlorizin treatment [10], we examined whether such a treatment could reverse the abnormal expression of several genes involved in key enzymes of hepatic glucose metabolism. Phlorizin administration to diabetic rats partially restored GK mRNA levels ( $40 \%$ of control values; 20 -fold rise compared with untreated diabetic rats), reversed PEPCK mRNA levels, but had no effect on LPK mRNA levels. All these effects of phlorizin may be related to hormonal changes (mainly lowering of hyperglucagonaemia) or correction of hyperglycaemia or both. Evidence has been presented that the mRNA levels of glycolytic enzymes (GK and L-PK) are increased by insulin and decreased by glucagon both in vivo [30-32] and in vitro [32-34]. In cultured hepatocytes, the inhibitory effect of glucagon dominates over the stimulatory effect of insulin in the control of the expression of these enzymes $[33,34]$. Thus, correction of hyperglucagonaemia may allow, in the presence of low - but still detectable - plasma insulin levels, a partial re-induction of GK mRNA in the liver of phlorizin-treated diabetic rats. In contrast to GK, whose transcription is glucose-independent [33], L-PK expression requires the presence of high glucose levels for its induction by insulin [34]. The lack of L-PK re-induction in phlorizin-treated diabetic rats could, therefore, be explained by the lowering of glycaemia, which prevented the effect due to the correction of hyperglucagonaemia.

Liver PEPCK gene expression is increased by glucagon and decreased by insulin both in vivo [35] and in vitro [32], and this regulation appears to be mainly glucose-independent [32]. It was first shown in hepatoma cells that the inhibitory effect of insulin on PEPCK transcription was predominant over the stimulatory effect of cAMP (second messenger of glucagon) [36]. However, hepatoma cells do not possess the enzyme pattern and hormone responsiveness of normal liver cells. In a more physiological model, namely primary cultures of hepatocytes, it was recently demonstrated that glucagon was predominant over insulin in the regulation of PEPCK expression [37]. Thus, the lowering of hyperglucagonaemia, again, may be the major mechanism which could account for the reduction of PEPCK expression in phlorizin-treated mildly insulindeficient rats. One cannot preclude, however, that the reversal of GK and PEPCK $m R$ NAs would have been less pronounced if more insulinopoenic rats were used.

Alterations in enzyme activities of treated diabetic rats paralleled changes in mRNA concentrations. In the fed state, PEPCK activity was however only partially restored, whereas PEPCK mRNA levels were decreased to values not significantly different from those in control rats. This may be due to the difference in half-lives, since it has been shown that, during refeeding, PEPCK activity decays more slowly $\left(\mathrm{t}_{1 / 2} \approx 6 \mathrm{~h}\right)$ [38] than the corresponding mRNA $\left(\mathrm{t}_{1 / 2} \approx 1 \mathrm{~h}\right)[35]$.

Although glycolytic and gluconeogenic fluxes were not measured in the present study, changes in enzyme activities are likely to reflect changes in their actual catalytic rates. Indeed, GK and PEPCK activities are not regulated by phosphorylation/dephosphorylation or by allosteric mechanisms. L-PK activity is markedly decreased by glucagon-mediated phosphorylation [22]. The active form of L-PK, which takes into account the phosphorylation state of the enzyme [22], has been measured in the current study. The changes in active form of L-PK paralleled the changes in maximal activity. On this basis, the present data strongly suggest that phlorizin treatment may partially shift liver gluconeogenesis into glycolysis in diabetic rats.

Glucose transport is not considered to be the ratelimiting step of hepatic glucose metabolism, and the major transporter GLUT 2 is involved in either net glucose uptake or release, depending upon the prevailing metabolic conditions [39]. In agreement with some [40,41], but not all [42], previous reports, a $50 \%$ rise in GLUT 2 mRNA was observed in the liver of streptozotocin-diabetic rats. GLUT 2 protein was also slightly increased. This could contribute to the enhanced hepatic glucose output from diabetic liver [40]. Altered abundance of GLUT 2 mRNA and protein was corrected by phlorizin treatment of diabetic rats. In vivo experiments with primary cultured hepatocytes have shown that GLUT 2 gene was increased by high glucose levels $[43,44]$ and decreased by insulin [44]. Evidence that such a regulation also occurred in vivo has recently been provided $[44,45]$. The potential regulatory role of glucagon on GLUT 2 has not yet been in- 
vestigated. However, correction of hyperglycaemia in the presence of low circulating insulinaemia may contribute to understanding the effects produced by phlorizin treatment on GLUT 2 expression in diabetic rats.

In conclusion, elimination of chronic hyperglycaemia by phlorizin glucuresis may allow some metabolic compensation in diabetic liver. Long-term phlorizin treatment of diabetic rats may induce a partial shift of the predominating gluconeogenesis, associated with hepatic glucose overproduction, into glycolysis, by correction of impaired pre-translational regulatory mechanisms. This could be essentially mediated through improvement of pancreatic alpha-cell function and subsequent lowering of hyperglucagonaemia. These observations suggest that glucagonstimulated hepatic glucose production results, in part, from glucose toxicity and reinforce the need for tight glycaemic control in diabetes.

Acknowledgements. We thank Drs. P. Iynedjian (Geneva, Switzerland), A.Kahn (Paris, France), R.W.Hanson (Cleveland, Ohio, USA) and B. Thorens (Lausanne, Switzerland) for kindly providing us with the cDNA probes and the antibody used in this study. We are grateful to Prof. R. Assan (Paris) for helpful suggestions and to $\mathrm{Mr}$. M. Gerard for hormone assays. This work was supported in part by Fondation de la Recherche Médicale (Paris) and by a Grant 1.5.078.92 from the FNRS (Brussels). S. M. B. acknowledges receipt of a fellowship from the Institut National de la Santé et de la Recherche Medicale.

\section{References}

1. Reaven GM, Sageman WS, Swenson RS (1977) Development of insulin resistance in normal dogs following alloxan-induced insulin deficiency. Diabetologia 13: 459-462

2. Blondel O, Portha B (1989) Early appearance of in vivo insulin resistance in adult streptozotocin-injected rats. Diabète Metab $15: 382-387$

3. Unger RH, Grundy S (1985) Hyperglycaemia as an inducer as well as a consequence of impaired islet cell function and insulin resistance: implications for the management of diabetes. Diabetologia 28: 119-121

4. Yki-Järvinen H (1990) Acute and chronic effects of hyperglycaemia on glucose metabolism. Diabetologia 33: 579-585

5. Bonner-Weir S, Trent DF, Weir GC (1983) Partial pancreatectomy in the rat and subsequent defect in glucose-induced insulin release. J Clin Invest 71: 1544-1553

6. Starke A, Grundy S, McGarry JD, Unger RH (1985) Correction of hyperglycemia with phlorizin restores the glucagon response to glucose in insulin-deficient dogs: implications for human diabetes. Proc Natl Acad Sci USA 82: 1544-1546

7. Rossetti L, Shulman GI, Zawalich W, De Fronzo RA (1987) Effect of chronic hyperglycemia on in vivo insulin secretion in partially pancreatectomized rats. J Clin Invest 80: 1037-1044

8. Yki-Järvinen H, Helve E, Koivisto VA (1987) Hyperglycemia decreases glucose uptake in type I diabetes. Diabetes 36: 892 896

9. Rossetti L, Smith D, Shulman GI, Papachristou D, De Fronzo RA (1987) Correction of hyperglycemia with phlorizin normalizes tissue sensitivity to insulin in diabetic rats. J Clin Invest 79: $1510-1515$

10. Blondel O, Bailbe D, Portha B (1990) Insulin resistance in rats with non-insulin-dependent diabetes induced by neonatal (5 days) streptozotocin: evidence for reversal following phlorizin treatment. Metabolism 39: 787-793

11. Lisato L, Cusin I, Tiengo A, Del Prato S, Jeanrenaud B (1992) The contribution of hyperglycaemia and hypoinsulinaemia to the insulin resistance of streptozotocin diabetic rats. Diabetologia $35: 310-315$

12. Kahn BB, Shulman GI, De Fronzo RA, Cushman SW, Rossetti L (1991) Normalization of blood glucose in diabetic rats with phlorizin treatment reverses insulin-resistant glucose transport in adipose cells without restoring glucose transporter gene expression. J Clin Invest 87:561-570

13. Dimitrakoudis D, Ramlal T, Rastogi S, Vranic M, Klip A (1992) Glycaemia regulates the glucose transporter number in the plasma membrane of rat skeletal muscle. Biochem J 284: 341-348

14. Chomczynski P, Sacchi N (1987) Single-step method of RNA isolation by acid guanidinium-thiocyanate-phenol-chloroform extraction. Anal Biochem 162: 156-159

15. Iynedjian PB, Ucla C, Mach B (1987) Molecular cloning of glucokinase cDNA. Developmental and dietary regulation of glucokinase $m$ RNA in rat liver. J Biol Chem 262:6032-6038

16. Simon MP, Besmond C, Cottreau D et al. (1983) Molecular cloning of cDNA for rat L-type pyruvate kinase and aldolase B.J Biol Chem 258: 14576-14584

17. Yoo-Warren H, Monahan JE, Short J et al. (1983) Isolation and characterization of the gene coding for cytosolic phosphoenolpyruvate carboxykinase (GTP) from the rat. Proc Natl Acad Sci USA $80: 3656-3660$

18. Thorens B, Sarkar HK, Kaback HR, Lodish HF (1988) Cloning and functional expression in bacteria of a novel glucose transporter present in liver, intestine, kidney, and B-pancreatic islet cells. Cell 55:281-290

19. Bradford M (1976) A rapid and sensitive method for the quantitation of microgram quantities of protein utilizing the principle of protein-dye binding. Anal Biochem 72:248-254

20. Laemmli UK (1970) Cleavage of the structural proteins during the assembly of the head of bacteriophage T4. Nature (Lond) 227: $680-685$

21. Newgard CB, Hirsch LJ, Foster DW, Mc Garry JD (1983) Studies on the mechanism by which exogenous glucose is converted into liver glycogen in the rat. J Biol Chem 258: 8046-8052

22. Blair JB, Cimbala MA, Foster JL et al. (1976) Hepatic pyruvate kinase. Regulation by glucagon, cyclic adenosine $3^{\prime}: 5^{\prime}$-monophosphate, and insulin in the perfused rat liver. J Biol Chem 251: $3756-3762$

23. Chang HC, Lane MD (1966) The enzymatic carboxylation of phosphoenolpyruvate. II. Purification and properties of liver mitochondrial phosphoenolpyruvate carboxykinase. J Biol Chem 241: $2413-2420$

24. Sokal RR, Rohlf FJ (1969) Biometry. The principles and practice of statistics in biological research. Freeman, San Francisco, pp $1-776$

25. Rossetti L, Laughin MR (1989) Correction of hyperglycemia with vanadate, but not with phlorizin, normalizes in vivo glycogen repletion and in vitro glycogen synthase activity in diabetic skeletal muscle. J Clin Invest 84: 892-899

26. Unger RH (1983) Insulin-glucagon relationships in the defense against hypoglycemia. Diabetes 32: 575-583

27. Muller WA, Faloona GR, Aguilar-Parada E, Unger RH (1971) Abnormal alpha-cell function in diabetes. Response to carbohydrate and protein ingestion. N Engl J Med 283: 109-115

28. Gruppuso PA, Susa JB, Domenech M et al. (1983) Chronic hyperglucagonemia in rats: effects on insulin, substrates and hepatic enzymes of intermediary metabolism. Metabolism 32: 911918

29. Del Prato S, Castellino P, Simonson DC, De Fronzo RA (1987) Hyperglucagonemia and insulin-mediated glucose metabolism. J Clin Invest 79: 547-556

30. Sibrowski W, Seitz HJ (1984) Rapid action of insulin and cyclic AMP in the regulation of functional mRNA coding for glucokinase in rat liver. $\mathrm{J}$ Biol Chem 259: 343-346

31. Vaulont S, Munnich A, Decaux JF et al. (1986) Transcriptional and post-transcriptional regulation of $\mathrm{L}$-type pyruvate kinase gene expression in rat liver. J Biol Chem 261: 7621-7625

32. Granner D, Pilkis S (1990) The genes of hepatic glucose metabolism. J Biol Chem 265: 10173-10176 
33. Iynedjian PB, Jotterand D, Nouspikel T, Asfari M, Pilot PR (1989) Transcriptional induction of glucokinase gene by insulin in cultured liver cells and its repression by the glucagon-cAMP system. J Biol Chem 264: 21824-21829

34. Decaux JF, Antoine B, Kahn A (1989) Regulation of the expression of the L-type pyruvate kinase gene in adult rat hepatocytes in primary culture. J Biol Chem 264: 11584-11590

35. Cimbala MA, Lamers WH, Nelson K, Monahan JE, Yoo-Warren H, Hanson RW (1982) Rapid changes in the concentration of phosphoenolpyruvate carboxykinase mRNA in rat liver and kidney. Effects of insulin and cyclic AMP. J Biol Chem 257: 7629 7636

36. Sasaki K, Cripe TP, Koch SR et al. (1984) Multihormonal regulation of phosphoenolpyruvate carboxykinase gene transcription. The dominant role of insulin. J Biol Chem 259: 15242-15251

37. Christ B, Nath A, Bastian H, Jungermann K (1988) Regulation of the expression of the phosphoenolpyruvate carboxykinase gene in cultured rat hepatocytes by glucagon and insulin. Eur $\mathbf{J}$ Biochem 178: 373-379

38. Hopgood MF, Ballard FJ, Reshef L, Hanson RW (1973) Synthesis and degradation of phosphoenolpyruvate carboxylase in rat liver and adipose tissue. Changes during a starvation-re-feeding cycle. Biochem J 134: 445-453

39. Mueckler M (1990) Family of glucose transporter genes. Implications for glucose homeostasis and diabetes. Diabetes 39: 6-11

40. Oka Y, Asano T, Shibasaki Y et al. (1990) Increased liver glucose-transporter protein and mRNA in streptozotocin-induced diabetic rats. Diabetes $39: 441-446$
41. Yamamoto T, Fukumoto H, Koh $\mathrm{G}$ et al. (1991) Liver and muscle-fat type glucose transporter gene expression in obese and diabetic rats. Biochem Biophys Res Commun 175: 995-1002

42. Thorens B, Flier JS, Lodish HF, Kahn BB (1990) Differential regulation fo two glucose transporters in rat liver by fasting and refeeding and by diabetes and insulin treatment. Diabetes 39 : 712-719

43. Asano T, Katagiri H, Tsukuda K et al. (1992) Upregulation of GLUT 2 mRNA by glucose, mannose, and fructose in isolated rat hepatocytes. Diabetes 41:22-25

44. Leturque A, Postic C, Burcelin R, Pegorier JP, Loizeau M, Girard J (1992) Regulation by insulin and glucose of GLUT 2 mRNA in rat liver: in vivo and in vitro studies. Diabetes 41 [Suppl 1]: 44A

45. Burcelin R, Eddouks M, Kandé J, Assan R, Girard J (1992) Evidence that Glut-2 mRNA and protein concentrations are decreased by hyperinsulinaemia and increased by hyperglycaemia in the liver of diabetic rats. Biochem J 288: 675-679

Received: 7 September 1992

and in revised form: 23 November 1992

Dr. J. Girard

Centre de Recherche sur l'Endocrinologie Moléculaire

et le Développement, CNRS

9, Rue Jules Hetzel

F-92190 Meudon-Bellevue

France 